\title{
A Comparative Study of Higher Degree Students' Financial Literacy Critical Factors of By Using Analytic Hierarchy Process
}

\author{
Khresna Bayu Sangka ${ }^{1 *}$, Renata Zoraifi ${ }^{2 *}$, Nurhasan Hamidi ${ }^{3 *}$, Sigit Santosa ${ }^{4 *}$ \\ * Universitas Sebelas Maret \\ Faculty of Teacher Training and Education \\ Jl. Ir Sutami No. 36A, Surakarta, 57126, \\ Indonesia \\ E-mail: b.sangka@staff.uns.ac.id
}

\begin{abstract}
As 2018 Global Competitiveness Index 4.0 ranking released by the World Economic Forum (WEF) shown that Indonesian economy was getting better, Indonesian knowledge in financial sector was fallen below the other nations. This study aimed to explore the determinants of financial literacy - intelligence that must be possessed by every individual to compete globally, by using Analytic Hierarchy Process as an analytical tool. There are five domains of financial literacy, namely (1) knowledge of financial concepts; (2) communication ability on financial sector; (3) the personal ability to financial management; (4) ability to make financial decisions; and (5) commitment to make future financial planning. Taking Universitas Sebelas Maret's Accounting Education Department students as focus of study, this study shown that there were insignificant differences between classes. While personal ability to financial management factor considers as the most important factor, followed by the knowledge of financial concept. Both factors are compulsory to be taken as part of financial majors in the department.
\end{abstract}

Keywords: AHP, financial literacy, higher degree students

\begin{abstract}
Abstrak
Berdasarkan peringkat 2018 Global Competitiveness Index 4.0 yang dikeluarkan oleh World Economic Forum (WEF) menunjukkan bahwa ekonomi Indonesia semakin baik, namun pengetahuan Indonesia di sektor keuangan jatuh di bawah negara-negara lain. Penelitian ini bertujuan untuk mengeksplorasi faktor-faktor penentu literasi keuangan sebuah kepandaian yang harus dimiliki oleh setiap individu untuk bersaing secara global, dengan menggunakan Analytic Hierarchy Process sebagai alat analisis. Ada lima domain literasi keuangan, yaitu (1) pengetahuan konsep keuangan; (2) kemampuan komunikasi di sektor keuangan; (3) kemampuan pribadi untuk manajemen keuangan; (4) kemampuan untuk membuat keputusan keuangan; dan (5) komitmen untuk membuat perencanaan keuangan masa depan. Mahasiswa Program Studi Pendidikan Akuntansi UNS diambil sebagai fokus studi, penelitian ini menunjukkan bahwa ada perbedaan yang tidak signifikan antara kelas (angkatan). Kemampuan pribadi untuk faktor manajemen keuangan dianggap sebagai faktor yang paling penting, diikuti oleh pengetahuan konsep keuangan. Kedua faktor tersebut wajib untuk diambil sebagai bagian dari jurusan keuangan di program studi terkait.
\end{abstract}

Kata kunci: AHP, literasi keuangan, mahasiswa perguruan tinggi

\section{Introduction}

Industrial Revolution 4.0 has become new challenge for everyone, specially for the $\mathrm{Z}$ generation. The emergence of automation technologies and integrated with the Internet and Internet of Things (IoT) obligatory require the improvement of human resources quality trough education process (Higher Education) to increase several skills and competencies and avoid literacies. Financial literacy, known as the ability a person is able to make decisions for his life and accept responsibility for their own actions, has took an essential role to shape higher degree students' future [1].

One intelligence that must be possessed by every individual is financial intelligence in managing his personal financial assets [2]. The ability of an individual includes 
knowledge, attitudes, and implementation in making decisions in managing personal financial assets called financial literacy [3]. According to research that been conducted to identify the financial literacy on higher degree student, a person is able to make decisions for his life and accept responsibility for their own actions [4].

Financial literacy domain could be divided into five domains [5] namely (1) Knowledge of financial concepts; (2) The ability to communicate about financial concepts; (3) the ability to manage personal finances; (4) ability to make financial decisions; and (5) confidence to make future financial planning. Furthermore, Program for International Student Assessment (PISA) financial literacy can be interpreted as knowledge and understanding of financial concepts and risks, and the skills, motivation and trust to apply that knowledge and understanding in effective decision making in various financial situations, to improve personal and community financial well-being, and to increase participation in economic life [6].

Evidence based on the 2016 National Literacy and Financial Inclusion Survey (SNLIK) conducted by the Financial Services Authority (OJK), the national financial literacy index increased from $21.8 \%$ in 2013 to $29.7 \%$ in 2016 [7]. This indicates that the level of public welfare has improved. This increase in prosperity encourages the potential of funds owned by the community to be invested. However, this is not matched by knowledge in all walks of life about investment products and financial literacy that is still very minimal.

Students are in a period of transition and dependence towards financial independence [8]. This is related to the related research conducted by Ariani and Susanti [4] which revealed to the earlier research that the lecture period is the first time students learn to manage finances independently without the supervision of parents. At this crucial time, students must learn to be financially independent and take full responsibility for the decisions they make [9]. Students have complex financial problems because some students do not yet have income and limited reserve funds to use each month [10]. Students must make financial planning because it will affect their prosperity and future success. In order for students to make good planning Nidar and Bestari also states that students need greater knowledge about personal finance and real life skills such as balancing income, managing expenses and using credit cards, providing budgets, saving, paying interest, or even follow insurance to achieve a prosperous future [9].

A lot of research has been done on students and the results shown that knowledge regarding the financial literacy in many circumstances is still low. According to the study from Lantara and Kartini [8] shows the level of student financial literacy is still far from optimum or still quite adequate, even close to the low category so it must be increased again, especially related to knowledge of financing, credit, savings, and investment. Meanwhile, according to research Nidar and Bestari (2012) it was concluded that the percentage of financial literacy of students was $57 \%$ or consider to below average. Based on the conditions above, this study aims to identify the comparative study of critical determinants of financial literacy in students by using the Analytic Hierarchy Process as an analysis tool. Comparison of the determination of identified factors can be used as a basis for improving the learning process through the development of higher education curriculum policies.

Department of Accounting Education is one of the existing department at Sebelas Maret University which is incorporated in the Faculty of Teacher Training and Education (FKIP), hosting 312 active student. Offering several courses related to financial and banking to address the financial literacy on student across semesters. But in fact, students or even graduates are unaware of their abilities and understanding in financial field. Meanwhile, the problem that might arose was the setting and plotting of the financial literacy related courses for students that need to consider in the future. It is related to the identified problem such as: 1) Lack of student consideration to aware on financial literacy related courses; 2) Financial literacy related courses were not structured sequentially. Many students were making decisions based on just one on one factors only without taking consideration to other factors; and 3) Lack of self-acknowledgment to conduct courses that match their needs and skills.

If the course is not able to be followed by students, it will create new problems for him. For this reason, students must consider various related factors, namely psychological and non-psychological factors before making the decision to take appropriate courses. Accuracy in organizing courses related to business and finance can also provide increased financial literacy in the future.

\section{Methods}

This study aims to facilitate decision making on behalf the comparison between classes. It could be used to develop policy as well as the development of lecture's material with a background on financial and accounting, by accommodating the result from decision support systems such as AHP (Analytic Hierarchy Process) method. AHP method has been proven to provide analysis in the form of recommendation of financial literacy related factors that have a weight that is a grade of value of each deciding choice.

Saaty [11] argues that AHP (Analytic Hierarchy Process) can raise priorities from the complexity of various choices or simulated factors. These priorities are also consistent with theory, logical and transparent. According to Saaty and Vargas [12], determining priorities is 
important from AHP implementation. Many researchers said that AHP is a theory about the concept of measurement. This method is used to get the ratio scale from the discrete and constant pair ratio. Comparisons are taken from existent criterion or from a baseline scale that reflects the strength of feelings and relative orientation [13]. The main tool of AHP is a functional hierarchy with the main input is the human perception of priorities between one element and another. The existence of a hierarchy allows the breakdown of complex problems in sub-problems, then arrange them into a form of hierarchy [14].

The population used in this study is the Department of Accounting Education in Sebelas Maret University, which consists of lecturers and students. Interviews with lecturers / expert councils are used to obtain justification for the hierarchical form of the problem at hand. The research sample is students in this Department. By using a clustered purposive sampling technique that aims to get complete and meaningful information. Data collection was carried out in accordance with AHP procedures, using two different methods. Structured interviews are used to obtain qualitative information, while questionnaires are used to obtain quantitative data. Data collection stage is as follow:

- Structured interview method. The interview which involved lecturers, study program head and students. There were 5 variables with 17 factors identified from literature review and focus group discussions between lecturer and students. Detailed hierarchical structure on this study could be seen as in Figure 1 .

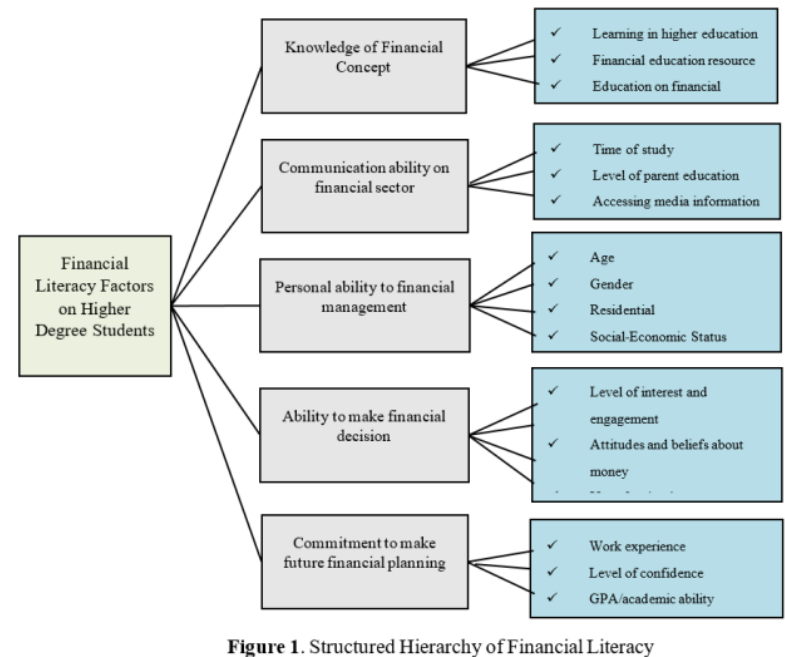

Each variable has their critical factors that varies from one to another. Focus group discussions have been conducted to define and decide the criterion on these factors in which will lead to the subjected variables.
- Questionnaire. To develop an applicable AHP model, all respondent have the answer all the questions of related financial factors baed on questionnaires procedure which is using pairwaise comparison matrix.

- Comparative Judgment. At some level there is a relationship between several levels where an assessment of two relative elements is needed. The results of this assessment can be shown by pairwise comparisons and presented in a matrix (Pairwise Comparasion) [15].

- Priority Determination (Synthesis of Priority). Each paired comparison matrix produces local priorities. Because at each level of the matrix has a pairwise comparison, for that in determining global priorities must synthesize each local priority. According to the hierarchy, the synthesis is not the same, an opinion is measured on a scale of 1 to 9 . Where 1 shows an equal priority level, while 9 shows the highest dominance of one choice over another [15].

- Logical Consistency. Consistency has two different meanings, first is the Eigenvalue shows similarities that can be put together and produce the same chosen object. The second is a specific condition which has a basic level of relationship between the objects being measured. The Consistency Ratio (CR) is used to find out how much influence or the effect of AHP implementation in answering existing problems [15]. 


\section{Findings and Discussion}

\section{Findings}

As basic nature of AHP, the identified factors need to be structured hierarchically, in this case, we defined financial literacy as the goal, while the five variables and 17 factors are identified to address the responses from the 156 valid respondents. The result of AHP prioritisation matrix judgement technique to find out the value of every variable and factor on the hierarchy. The values are presented in table 1 as follow.

TABLE 1. General Value on Financial Literacy

\begin{tabular}{|c|c|c|c|c|}
\hline \multirow{2}{*}{ Initial Factors } & \multirow{2}{*}{ Variables } & \multicolumn{3}{|c|}{ Value } \\
\hline & & \multicolumn{3}{|c|}{ Local Global Rank } \\
\hline \multirow{3}{*}{$\begin{array}{l}\text { Financial } \\
\text { concept } \\
\text { CR: } 0.0405\end{array}$} & $\begin{array}{l}\text { Learning in } \\
\text { Higher Education }\end{array}$ & 0.086 & \multirow[t]{3}{*}{0.301} & \multirow[t]{3}{*}{2} \\
\hline & $\begin{array}{l}\text { Financial } \\
\text { Education } \\
\text { Resource } \\
\end{array}$ & 0.067 & & \\
\hline & $\begin{array}{l}\text { Education on } \\
\text { Financial } \\
\text { Management } \\
\end{array}$ & 0.086 & & \\
\hline \multirow{3}{*}{$\begin{array}{l}\text { Communication } \\
\text { ability } \\
\text { CR: } 0.0613\end{array}$} & Time of Study & 0.031 & \multirow[t]{3}{*}{0.211} & \multirow[t]{3}{*}{3} \\
\hline & $\begin{array}{l}\text { Level of Parent } \\
\text { Education }\end{array}$ & 0.013 & & \\
\hline & $\begin{array}{l}\text { Accessing Media } \\
\text { Information }\end{array}$ & 0.103 & & \\
\hline \multirow{4}{*}{$\begin{array}{l}\text { Personal ability } \\
\text { CR: } 0.0598\end{array}$} & Age & 0.056 & \multirow[t]{4}{*}{0.346} & \multirow[t]{4}{*}{1} \\
\hline & Gender & 0.068 & & \\
\hline & Residential & 0.065 & & \\
\hline & $\begin{array}{l}\text { Social-Economic } \\
\text { Status Parents }\end{array}$ & 0.085 & & \\
\hline \multirow{4}{*}{$\begin{array}{l}\text { Financial } \\
\text { decision } \\
\text { CR: } 0.0720\end{array}$} & $\begin{array}{l}\text { Level of interest } \\
\text { and engagement }\end{array}$ & 0.006 & \multirow[t]{4}{*}{0.067} & \multirow[t]{4}{*}{5} \\
\hline & $\begin{array}{l}\text { Attitudes and } \\
\text { Beliefs About } \\
\text { Money } \\
\end{array}$ & 0.007 & & \\
\hline & Use of technology & 0.106 & & \\
\hline & $\begin{array}{l}\text { Monthly } \\
\text { Allowance }\end{array}$ & 0.009 & & \\
\hline \multirow{3}{*}{$\begin{array}{l}\text { Commitment to } \\
\text { the future } \\
\text { CR: } 0.0312\end{array}$} & Work Experience & 0.053 & \multirow[t]{3}{*}{0,047} & \multirow{3}{*}{4} \\
\hline & $\begin{array}{l}\text { Level of } \\
\text { Confidence }\end{array}$ & 0.088 & & \\
\hline & $\begin{array}{l}\text { GPA/Academic } \\
\text { Ability }\end{array}$ & 0.021 & & \\
\hline
\end{tabular}

Calculation that presented in table 1 shown that the "Use of technology" factor came as the most influenced factor as $10.6 \%$ contribution for the whole model. Followed with the "accessing media information" factor as much as $10.3 \%$, 'Level of confidence" factor came on third as $8.8 \%$ and the "parents social-economic status" came in the fourth. Furthermore the variable of personal ability shown as the most important variable to lead the financial literacy on higher degree student. This result is represent how the respondent stand on their point of view to define financial literacy.

Furthermore, the general result need to be broken down as the nature of the student. Following table shown final pairwise comparison between three different groups. These calculations are obtained from each respondent who responds to the importance of the factors identified in the selection criteria through their assessment of financial literacy as the ultimate goal. Based on these result, several interviews and discussion have been conducted in order to cross checked and the indicated findings. Table 2 below shown the general final comparative judgement of financial literacy factor on higher student.

TABLE 2. Student Pairwise Comparison on Financial Literacy Factors

\begin{tabular}{|c|c|c|c|c|c|c|}
\hline \multirow{2}{*}{$\begin{array}{l}\text { FINANCIAL } \\
\text { LITERACY }\end{array}$} & \multicolumn{2}{|c|}{ First Year } & \multicolumn{4}{|c|}{ Second Year Third Year } \\
\hline & Value & Rank & Value & Ran & Value & Rank \\
\hline $\begin{array}{l}\text { Financial } \\
\text { Concept }\end{array}$ & 0.311 & 2 & 0.313 & 2 & 0.280 & 2 \\
\hline $\begin{array}{l}\text { Communication } \\
\text { ability }\end{array}$ & 0.186 & 3 & 0.213 & 3 & 0.235 & 3 \\
\hline Personal ability & 0.362 & 1 & 0.327 & 1 & 0.349 & 1 \\
\hline $\begin{array}{l}\text { Financial } \\
\text { decision }\end{array}$ & 0.066 & 5 & 0.076 & 4 & 0.059 & 5 \\
\hline $\begin{array}{l}\text { Commitment to } \\
\text { future }\end{array}$ & 0.074 & 4 & 0.072 & 5 & 0.076 & 4 \\
\hline
\end{tabular}

\section{Discussion}

From the results AHP calculation and analysis can be expressed there are several differences on financial literacy prioritisation from first year to the third year students, especially for second year students. This group resulted differently to the others and the final calculation. Based on the interview conducted to the lecturers to assessed this finding, it could be noted that this group suggested met several changes in their lives. While in the first year, they tend to adapt to the social-cultural situation from high school to the university live. Second year, student meet the experience and education of financial factors consisting of learning variables in college, age, source of financial education, work experience, length of study, access to information media and Grade Point Average (GPA) that shown students' academic ability. It is related to Gill and Bhattacharya (2019) [16] in which suggested that learning in college or higher degree, especially in business and finance domains will affects the level of financial literacy.

Therefore, lecturers need to make lesson plans and pay attention to the applied learning strategy, the use of methods and instructional media, and evaluation techniques in accordance with the learning objectives. These methods 
should be done because they will determine the success of students in understanding and implementing the material received in life.

The financial literacy is also influenced by the age factor or personal ability. Age indicates the amount of experience a person experiences during his lifetime including experience in financial matters. It is relevant to the research conducted by Young in 2013 [17]. Senior students will have a better attitude in making financial decisions than junior students because senior students have more experience in this regard. Financial education should be given to individuals early on so that the level of financial literacy they have is getting higher as they get older.

The source of information on financial education and concept also affects the level of one's financial literacy. The more the source of financial education obtained by students the better the ability to manage finances. Students who have a high curiosity about finance will utilize books or other learning media to improve their financial knowledge. Students who have a habit of accessing information media to seek information related to finance will have a degree of financial literacy compared to students who do not access information for similar purposes.

Therefore, accessing information media in seeking information related to finance needs to be familiarized so that the level of one's financial literacy becomes higher. The student work and communication experience has a positive effect on the level of financial literacy. Students with working experience will have better financial management skills than students who do not have working experience. In the work period should someone learn to plan, manage and make decisions related finances appropriately, so that with increasing experience during work can also increase the financial literacy owned. It is coherence to the study from Potrich, Viera and Kirch (2015) [18] who determine the financial literacy based on demographic factors.

Interviews with lecturers and students also shown that the longer students study the financial sector in higher education, the higher the level of financial literacy. The duration of study gives positive influence to student's financial literacy. The longer the college student, the more subjects he gets. Financial literacy can be supported by improving the existing lecture system in a college such as the addition of courses related to finance that can increase student financial literacy to shape their commitment to the future.

\section{Conclusions and Recommendations}

\section{Conclusion}

Based on the analysis and discussion of the factors that affect the financial literacy of at higher degree student at department of Accounting education Faculty of Teaching and Education, Universitas Sebelas Maret concluded that there are five factors that influence financial literacy students of Accounting Education, namely: financial concept, communication ability, personal ability, financial decision and commitment to the future. The results of AHP of this study shown that there is slight or insignificant difference prioritisation among three different groups or classes. The first group suggested have the same prioritisation for the proposed financial literacy factors. While the second group has different in prioritize the fourth and fifth factors accordingly.

Calculations' result has drawn big picture in how the higher degree students in this context react and interpret the importance of financial knowledge to their daily life. Furthermore, it could be concluded that those factors are potentially shaping their future. Mastering personal ability and financial concept suggested as a critical combination to handle the unforeseen financial risk might occurred after the complete their study. It is also important to student who were financially influenced by their environment (including friends, parents, and organisations) to have higher financial knowledge, attitude, and behavior. Even financial decision factor suggested to the least important factor, it is also very important to highlight the ability of student to decide and decide in how financial products might overcome benefits and advantages in the short and long terms. Third year group suggested already has wider knowledge in financial related learning material. The financial decision factor has become the least important factor in this group, shown the high level of careful behavior to decide what kind of investment or any financial related agenda.

Final remark of this study is that AHP simulation and computation has created the more distinct and fixed result in shaping the student motives and needs of defining the financial literacy to them, related to the decision judgement of students in the proposed variables and factors. Thus, it is recommended to develop a set of policy that covers their need. Meanwhile, validity test trough consistency ratio is important to measure the construct of the factors which influencing student decisions and the results could be optimized. The study imply that the financial literacy of the students are critical to applied on a complete curriculum to avoid the financial literacy. Furthermore, it is also important to create and develop policies, programme, or activities on how to reduce the financial literacy and improve the awareness of finance managerial on non-economics or nonaccounting department.

\section{Recommendation}

Based on the conclusions that have been outlined above, lecturers and departments' manager (department head) are recommended to use various learning models for 
Millennial students in order to accommodate the financial literacy as well as accessing information media as an important part of financial decision factor which could affect student to master the financial literacy understanding.

Learning model such as problem-based learning suggested is better to be applied for this subject rather than any other learning model. Further Research is expected to conduct research related to on financial literacy broader and deeper through the addition of other variables as well be applied to other departments across the University to get better understanding in financial literacy.

\section{References}

A. Homan, H.S. Comparative Study of Students Financial Literacy And Its Demographic Factors. in International Conference on Economics and Banking (iceb-15). 2105.

B. Ansong, A. and M.A. Gyensare, Determinants of University WorkingStudents' Financial Literacy at the University of Cape Coast, Ghana. International Journal of Business and Management 2012. 7 (9): p. 126-133.

C. Chen, H. and R.P. Volpe, An analysis of personal financial literacy among college students. Financial Services Review, 1998. 7(2): p. 107-128.

D. Ariani, N.A. and Susanti, Pengaruh Faktor Demografi Terhadap Financial Literacy Mahasiswa Fakultas Ekonomi Universitas Negeri Surabaya Angkatan 2012. Jurnal Mahasiswa Teknologi Pendidikan, 2015. 3(2): p. 1-11.

E. Remund, D.L., Financial Literacy Explicated: The Case for a Clearer Definition in an Increasingly Complex Economy. Journal of Consumer Affairs, 2010. 44(2).

F. Thompson, S., L.D. Bortoli, and S. Buckeley, PISA 2012: how Australia measures up : the PISA 2012 assessment of students' mathematical, scientific and reading literacy. 2013, Australian Council for Educational Research (ACER): Melbourne.

G. OJK, OJK Announces Higher Financial Literacy And Inclusion Indices, A. Sugiarto, Editor. 2017, Otoritas Jasa Keuangan: Jakarta.

H. Lantara, I.W.N. and N.K.R. Kartini, Financial Literacy Among University Students: Empirical Evidence From Indonesia. Journal of Indonesian Economy and Business, 2015. 30(3): p. 247-256.
I. Nidar, S.R. and S. Bestari, Personal Financial Literacy Among University Students(Case Study at Padjadjaran University Students, Bandung,Indonesia). World Journal of Social Science, 2012. 2(4): p. 162-171.

J. Nurhidayati, S.E. and M.K. Anwar, Pengaruh Faktor Demografi Terhadap Literasi Keuangan Syariah Karyawan Perbankan Syariah Di Surabaya. Jurnal Ekonomi Islam, 2018. 1(1): p. 1-12.

K. Saaty, T.L., Fundamentals of the Analytic Network Process - Dependence and Feedback in DecisionMaking with a Single Network. Journal of System Science and System Engineering, 2004. Vol. 13(No. 2): p. pp. 129-157.

L. Saaty, T.L. and L.G. Vargas, Models, Methods, Concepts \& Applications of the Analytic Hierarchy Process. 2012, US: Springer. 346-346.

M. Saaty, T.L., Decision Making for Leaders - The Analytic Hierarchy Process for Decision in a Complex World. 2001, Pittsburgh, USA: RWS Publication.

N. Turban, E., J.E. Aronson, and T.-P. Liang, Decision Support Systems and Intelligent Systems (7th Edition). 2004, Upper Saddle River, NJ, USA @2004: PrenticeHall, Inc. .

O. Saaty, T.L., Fundamentals of Decision Making and Priority Theory With the Analytic Hierarchy Process. Vol. 6. 2000: RWS Publications. 478-478.

P. Gill, A. and R. Bhattacharya, The effects of a financial literacy intervention on the financial and economic knowledge of high school students. THE JOURNAL OF ECONOMIC EDUCATION, 2019. 50(3): p. 215 229.

Q. Young, J.H., Financial literacy: Age and experience as the determinants. Washington Business Research Journal, 2013. 3(1): p. 36-46.

R. Potrich, A.C.G., K.M. Vieira, and G. Kirch, Determinants of Financial Literacy: Analysis of the Influence of Socioeconomic and Demographic Variables. Revista Contabilidade \& Finanças, 2015. 26(69). 